\title{
Nefroprotective Effect of Gynura procumbens Extract Against Paracetamol Toxicity in Rats
}

\author{
Pertiwi Ishak $^{1}$, Peter Kabo², Yulia Yusrini Djabir ${ }^{3 *}$

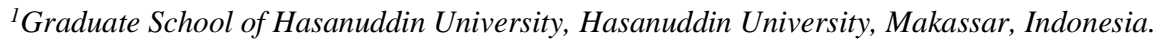 \\ ${ }^{2}$ Department of Pharmacology, Faculty of Medicine, Hasanuddin University, Makassar, Indonesia . \\ ${ }^{3 *}$ Department of Pharmacy, Faculty of Pharmacy, Hasanuddin University, Makassar, Indonesia. \\ *E-mail: yulia.yusrini@unhas.ac.id
}

Article Info:

Received: 9 August 2021

in revised form: 9 September 2021

Accepted: 8 October 2021

Available Online: 10 October 2021

Keywords:

Gynura procumbens

Nephroprotective

Paracetamol

Corresponding Author:

Yulia Yusrini Djabir

Department of Pharmacy

Faculty of Pharmacy

Hasanuddin University

Makassar

90245

Indonesia

email: yulia.yusrini@unhas.ac.id

\begin{abstract}
Excessive doses of paracetamol have the potential to cause acute kidney injury and even death. Gynura procumbens has been traditionally used as folk-medicine for kidney disease. This study aimed to examine the nephroprotective effect of Gynura procumbens leaf extract against paracetamol-induced nephrotoxicity in rats. Twenty-five male wistar rats (150-200 g) were divided into 5 groups. Healthy control group, placebo group, and 3 extract treatment groups that received either $100 \mathrm{mg} / \mathrm{kg}, 200$ $\mathrm{mg} / \mathrm{kg}$ or $300 \mathrm{mg} / \mathrm{kg}$ dose. The placebo (sodium carboxymethyl cellulose) or extract was given in 4 consecutive days prior to paracetamol (2400 $\mathrm{mg} / \mathrm{kg}$ ) administration on day 5. Blood samples were withdrawn before treatment initiated (day 0), after treatment before paracetamol administration (day 5) and 24-hour after paracetamol administration (day 6). Blood samples were analyzed to obtain urea and creatinine levels. In addition, histopathological analysis was performed on the renal tissue. Paracetamol administration was shown to significantly increase the urea and creatinine levels, and the extract at $300 \mathrm{mg} / \mathrm{kg}$ dose was able to significantly prevent the elevation of the renal biomarkers. The histopathological analysis also revealed a significant reduction in renal histopathological injury in $300 \mathrm{mg} / \mathrm{kg}$ extract group. It can be concluded that the ethanolic extract of the Gynura procumbens at a dose of $300 \mathrm{mg} / \mathrm{kg}$ has a good protective effect on kidney function and tissue structure.
\end{abstract}

How to cite (APA $6^{\text {th }}$ Style):

Ishak, P., Kabo, P., Djabir, Y. Y. (2021). Nefroprotective Effect of Gynura procumbens Extract Against Paracetamol Toxicity in Rats. Jurnal Farmasi Galenika :Galenika Journal of Pharmacy (e-Journal), 7(2), 181-190. doi:10.22487/j24428744.2021.v7.i2.15584 


\begin{abstract}
ABSTRAK
Dosis parasetamol yang berlebihan berpotensi menyebabkan cedera ginjal akut bahkan kematian. Secara tradisional Gynura procumbens digunakan sebagai obat tradisional untuk penyakit ginjal. Penelitian ini bertujuan untuk menguji efek nefroprotektif ekstrak daun Gynura procumbens terhadap nefrotoksisitas akibat parasetamol pada tikus. Dua puluh lima ekor tikus wistar jantan (150-200 g) dibagi menjadi 5 kelompok. Kelompok kontrol sehat, kelompok plasebo, dan 3 kelompok perlakuan ekstrak yang menerima dosis $100 \mathrm{mg} / \mathrm{kg}, 200 \mathrm{mg} / \mathrm{kg}$ atau 300 $\mathrm{mg} / \mathrm{kg}$. Plasebo (Na-CMC) atau ekstrak diberikan dalam 4 hari berturut-turut sebelum pemberian parasetamol $(2400 \mathrm{mg} / \mathrm{kg}$ ) pada hari ke-5. Sampel darah diambil sebelum pengobatan dimulai (hari ke-0), setelah pengobatan sebelum pemberian parasetamol (hari ke-5) dan 24 jam setelah pemberian parasetamol (hari ke-6). Sampel darah dianalisis untuk mendapatkan kadar ureum dan kreatinin. Selain itu, analisis histopatologi dilakukan pada jaringan ginjal. Pemberian parasetamol terbukti secara signifikan meningkatkan kadar ureum dan kreatinin, dan ekstrak pada dosis $300 \mathrm{mg} / \mathrm{kg}$ mampu secara signifikan mencegah peningkatan biomarker ginjal. Analisis histopatologi juga mengungkapkan penurunan signifikan pada cedera histopatologi ginjal pada kelompok ekstrak $300 \mathrm{mg} / \mathrm{kg}$. Dapat disimpulkan bahwa ekstrak etanolik Gynura procumbens dengan dosis $300 \mathrm{mg} / \mathrm{kg}$ memiliki efek protektif yang baik terhadap fungsi ginjal dan struktur jaringan.
\end{abstract}

Key words: Gynura procumbens, Nefroprotektif, Parasetamol.

\title{
INTRODUCTION
}

Kidney injury is a global public health problem with an increasing prevalence and incidence of kidney failure. The results of the Global Burden of Disease survey implicate that kidney-related disease have been one of top 20 leading cause of death in the world in 2010. The results of national report in 2013 showed that prevalence increased with increasing age between the 35 to 44 years old group compared to the 25 to 34 years old group (Kemenkes RI, 2017). The incidence of kidney failure patients in Indonesia is estimated at approximately 50 people per one million population, which generally caused by glomerulonephritis, essential hypertension, and pyelonephritis. In addition to these factors, there are also several causes associated with the increased incidence of kidney failure, including smoking, energy drinks, use of anti-pain drugs, and non-steroid antiinflammatory drugs (NSAIDs). Misuse of analgesic drugs and NSAIDs in the long term can trigger papillary necrosis and chronic kidney failure (Pranandari and Supadmi, 2015).

Paracetamol is widely used either as a single dosage form or in combination with other drugs. Paracetamol is easily found and bought over the counter without a doctor's prescription. It has been the world's most widely used first-line drug since 1950. Therefore, the risk of drug poisoning from an overdose of paracetamol increases. In Indonesia, it was found 305 types of drugs containing paracetamol in 2006, and according to data from the Food and Drug Administration Agency, there were 201 cases of poisoning due to paracetamol in Indonesia in 2002-2005. In some cases, the kidneys are damaged without any damage to the liver. The dose required to cause kidney damage is lower than that of the liver. Excessive doses of paracetamol have the potential to cause kidney failure and even death.

Nephrotoxicity due to paracetamol is characterized by the morphological and functional changes of the kidneys which are characterized by damage to the proximal tubules in humans and animals. The damage 
is caused by oxidative stress triggered by reactive metabolites of paracetamol (Lorz et al, 2004). Oxidative stress caused by paracetamol can be prevented using antioxidants.

The succulent leaves of Gynura procumbens are often used as medicine and health food/drinks, and usually packed in herbal teas or capsules. Traditionally, it is used as a medicine for kidney disease, esophageal infections, stopping bleeding, and antidote to venomous animal bites. Phytochemicals contained in the leaves is thought to be efficacious to act as anti-cancer. In vivo, the flavonoid content of Gynura procumbens leaves has been shown to actively inhibit free radicals caused by cytotoxicity by peroxidation (Fadli, 2015). In vitro, flavonoids inhibit lipid peroxidation, and at the initiation stage, they act as a binder of superoxide anions and hydroxyl radicals (Fadli, 2015). However, the use of extracts of the leaves of Gynura procumbens leaves has not been studied for their nephroprotective effects. Purwitasari et al. study (2016) showed that the best antioxidant activity of Gynura procumbens leaf extract was obtained using $70 \%$ ethanol as solvent. Based on that, this study aimed to examine the nephroprotective effect of Gynura procumbens leaf extract against paracetamol-induced nephrotoxicity in rats.

\section{MATERIAL AND METHODS}

\section{Materials}

The leaves of Gynura procumbens were obtained from Tamalanrea district of Makassar and was authenticated by the Community Traditional Health Center of Makassar. Male rats (Wistar strain) were provided and cared for in Biopharmacy Laboratory, Faculty of Pharmacy, Hasanuddin University. Other chemicals, such as ethanol 70\%, paracetamol powder, ether, sodium carboxymethyl cellulose (Na CMC) and formaldehyde $10 \%$ were purchased from local chemical distributors.

\section{Animal preparation}

Twenty-five male rats, 2-3 months of age with 150-200 grams of weight, were used in this study. The rats were ensured to have no anatomical abnormalities and show no sign of illnesses. The rats were caged with a 12-hour lighting cycle and were given standard food and drink ad libitum. This study has been approved by ethics committee of Medical Faculty of Hasanuddin university with the protocol number of UH21010201.

\section{Sample preparation and extraction}

The leaves of Gynura procumbens were sorted and washed with running water until clean, then cut into small pieces and dried. As much as 500 grams of simplicial powder of Gynura procumbens leaves was put into a maceration vessel. Ethanol (70\%) was added with a ratio of 1:7.5 then left for 3 days while

$\underline{\text { stirring occasionally. After } 3 \text { days, the extract was filtered using flannel cloth, and the residue obtained }}$ 
was re-macerated with $70 \%$ ethanol. The treatment was repeated until the solvent was colorless. The yield obtained was collected and evaporated with a rotary evaporator to obtain a thick extract.

\section{Experimental procedures}

Rats were divided into 5 groups, including healthy control group, placebo group, and 3 extract treatment groups that received either $100 \mathrm{mg} / \mathrm{kg}, 200 \mathrm{mg} / \mathrm{kg}$ or $300 \mathrm{mg} / \mathrm{kg}$ dose. The placebo (Na-CMC) or extract was given in 4 consecutive days prior to paracetamol $(2400 \mathrm{mg} / \mathrm{kg})$ administration on day 5 . Blood samples were withdrawn before treatment was initiated (day 0), after treatment before paracetamol administration (day 5) and 24-hour after paracetamol administration (day 6). The rat's blood samples were taken via the lateral vein. These blood samples were analyzed to obtain the baseline, post-treatment and post-paracetamol induction levels of urea and creatinine. Following blood withdrawal, the rats were euthanized with cervical dislocation and the kidneys were removed.

\section{Blood Analysis}

The collected blood was placed in tubes containing EDTA and then centrifuged at a speed of $2500 \mathrm{rpm}$ for 15 minutes. The serum was separately collected from the blood cells, placed into Eppendorf tubes and stored in the refrigerator $(4 \mathrm{oC})$ until analyzed. The creatinine and urea analysis were performed based on kit's instruction as previously described in Djabir et al (2021a) study.

\section{Histopathological Analysis}

The specimens of kidney organs were immediately fixed with $10 \%$ formalin buffer and were cut into a thickness of $0.5-1 \mathrm{~cm}$. The embedding cassette containing the cut specimen was processed on a tissue processor. When the specimen was ready to embed in paraffin, it was thinly sliced using a microtome with a thickness of 4-5 m. The staining process was carried out using Mayer's hematoxylin and eosin. Histopathological analysis of rat kidney was measured qualitatively using the Mitchel method (2001) and the parameters observed including the level of hemorrhage, vacuolysis and renal cellular necrosis.

\section{Statistical Analysis}

The statistical analysis was performed using spss 25 software. The normality of the data is tested using a shapiro-wilk analysis. If the data obtained were normal, it was continued by the analysis of variance, then followed by post hoc analysis. If the data was not normally distributed, then the data was analyzed using a kruskall-wallis analysis, followed by the mann whitney test. 


\section{RESULTS AND DISCUSSION}

This study aimed to determine the protective effect of Gynura procumbens extract against kidney injury caused by paracetamol toxicity. The excessive use of paracetamol can cause kidney damage. Ikawati, (2010) explained that the cellular damage by paracetamol is caused by the formation of toxic reactive metabolites ( $\mathrm{N}$-acetyl-p-benzoquinone) and free radicals through the process of biotransformation by cytochrome P450 enzymes with the help of CYP2EI isoenzymes. Toxic reactive metabolites and free radicals can disrupt the integrity of cell membranes and lead to liver damage and kidney failure.

The presence of kidney dysfunction can be indicated by a marked increase in plasma creatinine and urea levels (Djabir et al, 2021b). In this study, the creatinine and urea levels of rats before treatment (day 0), after treatment (day 5), and after paracetamol induction (day 6) can be seen in figure 1.
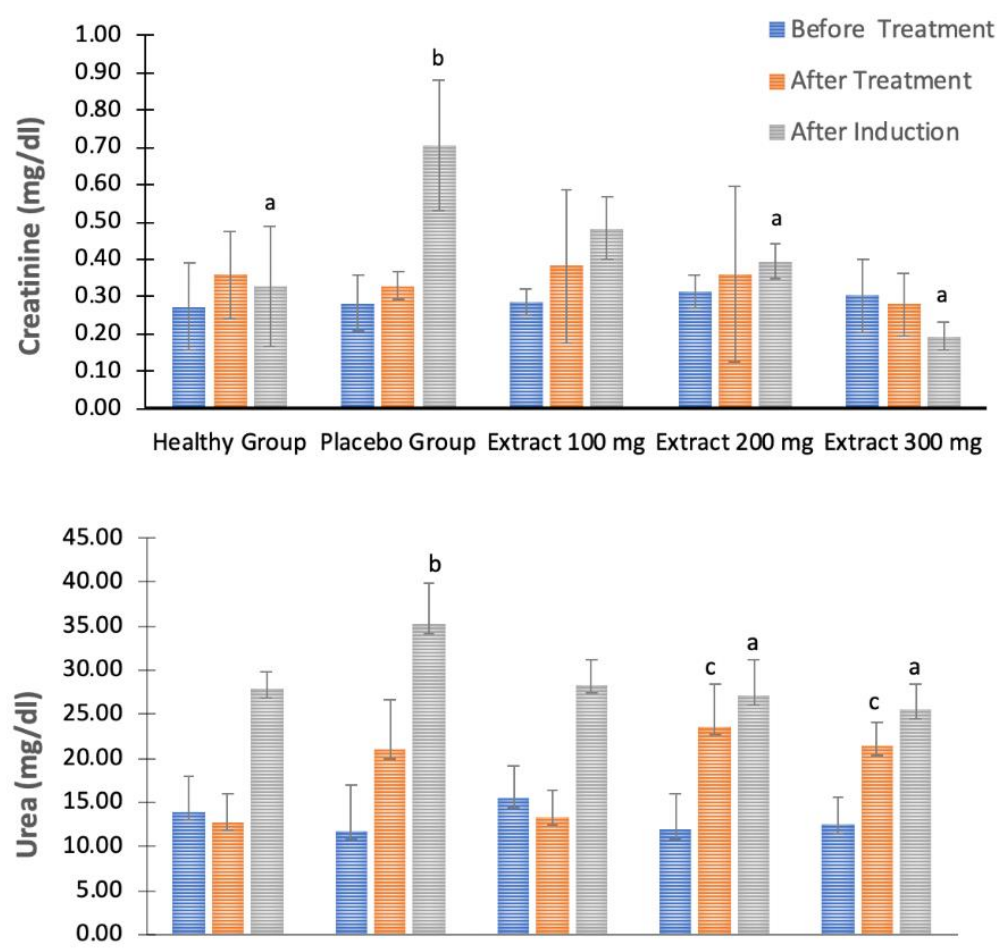

Figure 1. The plasma creatinine and urea levels of rat groups before and after receiving treatments and after induction of paracetamol. a: $\mathrm{p}<0.05$ vs placebo group after paracetamol induction, $b$ : $p<0.05$ vs healthy group after paracetamol induction, $\mathrm{c}$ : $\mathrm{p}<0.05$ vs healthy control after treatment.

Plasma creatinine and urea levels increased along with a decrease in the filtration rate of the glomerulus. Plasma creatinine levels is a good indicator of the presence of kidney injury because creatinine is constantly produced by the body and also constantly removed via glomerulus. The higher the level of urea and creatinine in the plasma indicates the higher the level of damage in kidney cells. The normal value of creatinine in rats is $0.2-0.8 \mathrm{mg} / \mathrm{dL}$, and for urea, the normal level is $15-21 \mathrm{mg} / \mathrm{dL}$ (Malole and Pramono, 1989) 
From the results, before treatment the mean value of creatinine levels was $0.27 \mathrm{mg} / \mathrm{dl}$ in healthy control, $0.29 \mathrm{mg} / \mathrm{dl}$ in placebo group, $0.29 \mathrm{mg} / \mathrm{dl}$ in extract $100 \mathrm{mg}$ group, $0.32 \mathrm{mg} / \mathrm{dl}$ in extract $200 \mathrm{mg} / \mathrm{kg}$ group and $0.30 \mathrm{mg} / \mathrm{dl}$ in extract $300 \mathrm{mg} / \mathrm{kg}$ group. Meanwhile, the average of urea level in the healthy group was $13.97 \mathrm{mg} / \mathrm{dl}$, the NaCMC group was $11.82 \mathrm{mg} / \mathrm{dl}$, the $100 \mathrm{mg}$ extract group was $15.48 \mathrm{mg} / \mathrm{dl}$, the $200 \mathrm{mg}$ extract group was $11.86 \mathrm{mg} / \mathrm{dl}$ and the $300 \mathrm{mg}$ extract group was $12.51 \mathrm{mg} / \mathrm{dl}$. From statistical analysis, there was no significant difference on the baseline values among groups. This indicates that the kidney conditions of all rats were still normal and has no difference before treatment.

After day 6, following paracetamol administration at a dose of 2,400 mg/kg, there was an increase in creatinine and urea levels. This indicates that paracetamol is capable of causing kidney damage or nephrotoxicity at the dose given in rats. This elevation of urea and creatinine was experienced in all treatment groups except for rats receiving Gynura procumbens extract at a dose of $300 \mathrm{mg} / \mathrm{kg}$ ( $\mathrm{p}<0.05)$. Indeed, there was a decrease in creatinine levels compared to baseline.

The result of histopathological examination of the kidneys can be found in table 1. It was found no abnormality or cellular injury in the healthy control as seen in Figure 2. In contrast, in the placebo group, all rats experienced kidney damage, including cell degeneration, necrosis, and bleeding in the kidneys with the percentage of damage ranging from $50-75 \%$ (Figure 3 ).

Table 1. Renal histology level of damage

\begin{tabular}{|c|c|c|c|}
\hline Groups & $\begin{array}{l}\text { Rat } \\
\text { code }\end{array}$ & $\begin{array}{l}\text { Level of } \\
\text { Damage }\end{array}$ & Renal injury parameters \\
\hline \multirow{5}{*}{ Healthy Group } & 1 & - & No abnormality \\
\hline & 2 & - & No abnormality \\
\hline & 3 & - & No abnormality \\
\hline & 4 & - & No abnormality \\
\hline & 5 & - & No abnormality \\
\hline \multirow{5}{*}{ Placebo Group } & 1 & 2 & Degeneration, bleeding \\
\hline & 2 & 3 & Degeneration \\
\hline & 3 & 3 & Necrosis \\
\hline & 4 & 2 & Degeneration \\
\hline & 5 & 2 & Degeneration \\
\hline \multirow{4}{*}{ Extract $100 \mathrm{mg}$} & 1 & 2 & Hemorrhagic, degeneration \\
\hline & 2 & 3 & Necrosis, degeneration \\
\hline & 3 & 2 & Degeneration \\
\hline & 4 & 1 & Degeneration \\
\hline
\end{tabular}




\begin{tabular}{lllc}
\hline & 5 & 2 & Degeneration \\
\hline & 1 & 2 & Hemorrhagic, degeneration \\
Extract $200 \mathrm{mg}$ & 2 & 3 & Hemorrhagic, degeneration \\
& 4 & 1 & Hemorrhagic, degeneration \\
& 5 & 1 & Demorrhagic, degeneration, inflammation \\
\hline & 1 & 1 & Degeneration \\
& 2 & 1 & Degeneration \\
& 3 & - & No abnormality \\
& 4 & 1 & Degeneration, hemorrhagic \\
\hline
\end{tabular}

$0 /$ - = Normal; $1=<25 \%$ damage $; 2=26-50 \%$ damage; $3=51-75 \%$ damage $;=>75 \%$ damage
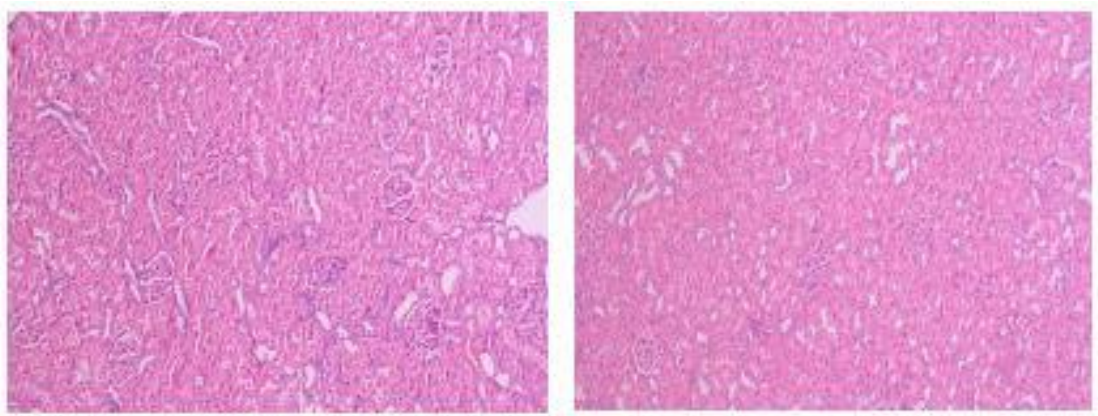

Figure 2. Microscopic view of rat kidney tissue in the healthy group showing no abnormality

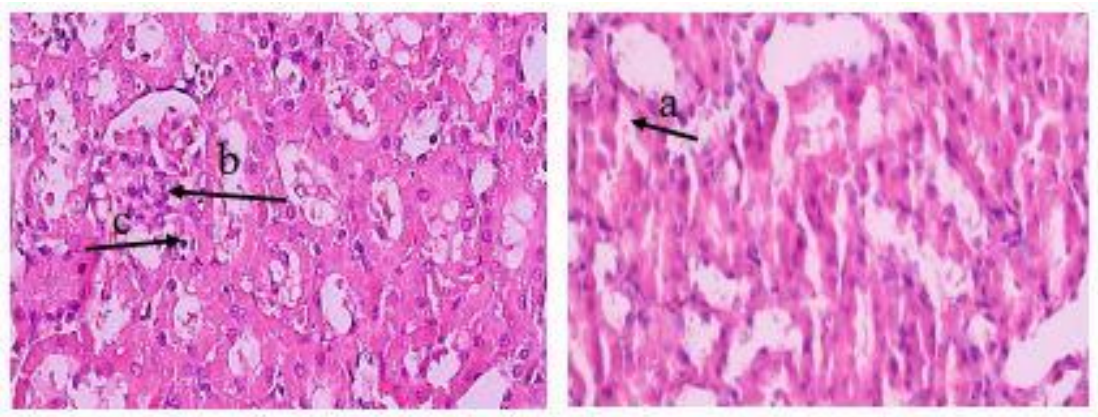

Figure 3. Microscopic view of rat kidney tissue with 51-75\% in the negative control group. (a) bleeding, (b) glomerular degeneration, (c) necrosis of tubular cells. 

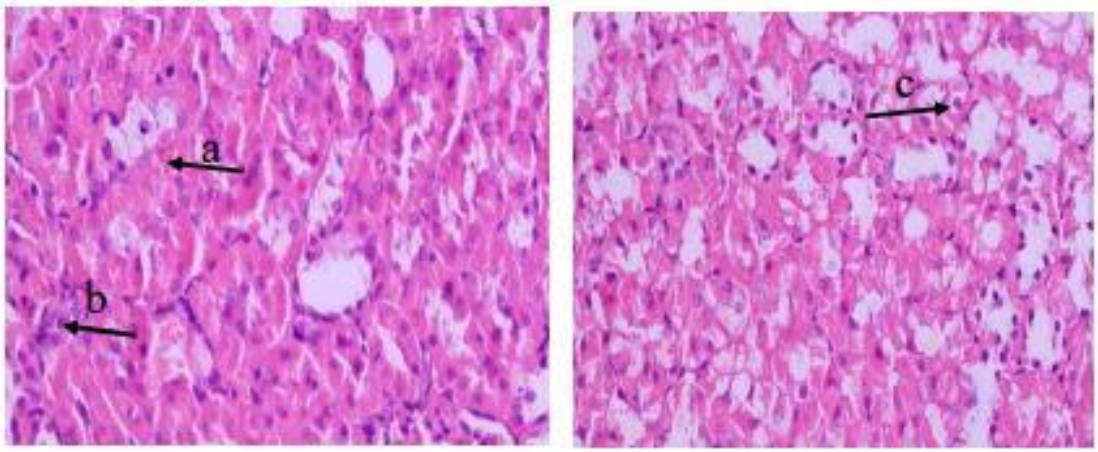

Figure 4. Microscopic view of rat kidney tissue with damage of $26-50 \%$ in the $100 \mathrm{mg} / \mathrm{KgBW}$ extract group, (a) hemorrhage, (b) necrosis, (c) tubular degeneration
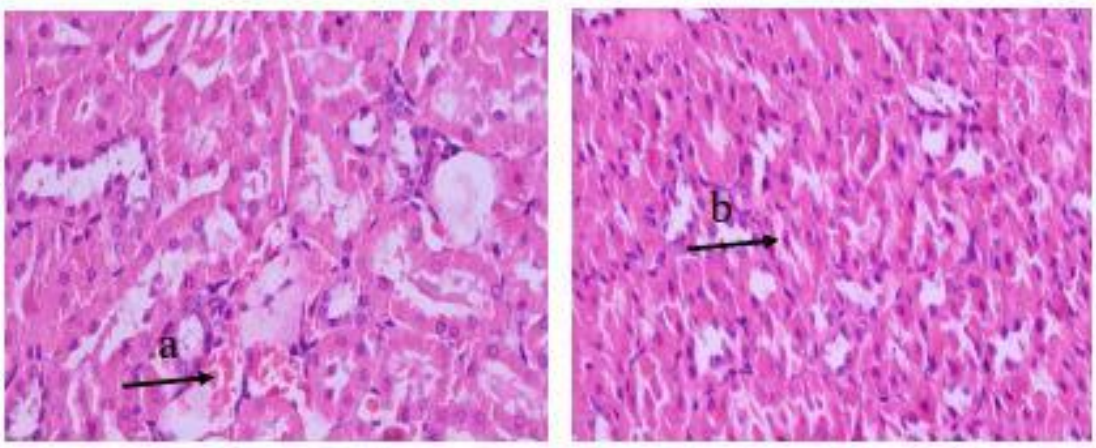

Figure 5. Microscopic view of rat kidney tissue with damage of $26-50 \%$ in the $200 \mathrm{mg} / \mathrm{KgBW}$ extract group, (a) hemorrhage, (b) tubular degeneration.
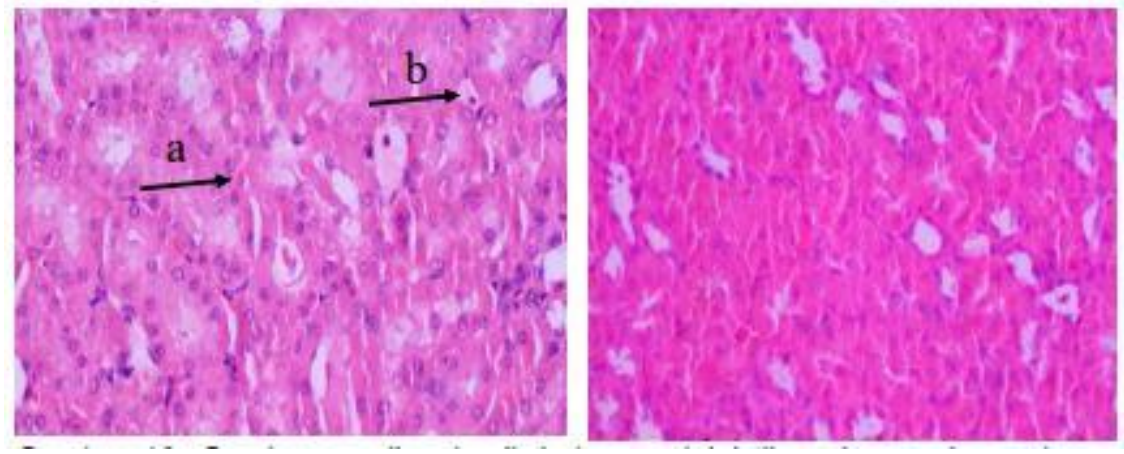

Figure 6. Microscopic view of rat kidney tissue with damage $<25 \%$ in the $300 \mathrm{mg} / \mathrm{KgBW}$ extract group, (a) hemorrhage, (b) degeneration.

At a dose of $100 \mathrm{mg} / \mathrm{kg}$ extract, kidney damage still occurred in all rats in the group. The visible damage included hemorrhagic, degeneration and necrosis (Figure 4) with the level of damage ranging from 50$75 \%$. In the extract dose group of $200 \mathrm{mg} / \mathrm{kg}$, the damage was characterized by hemorrhagic, degeneration and inflammation (Figure 5) with a smaller percentage of damage, ranging from 26-50\%. 
While in the extract dose group of $300 \mathrm{mg} / \mathrm{kg}$, the damage occurred almost diminished in all rats, although some histological changes were found, such as hemorrhagic and cellular degeneration (Figure 6). However, the percentage of damage was quite low $(<25 \%)$, and there was even 1 rat in this group that did not experience abnormalities in the renal structure.

The results of creatinine and urea level measurement was supported by the histopathological examination of the kidneys, showing that the nephroprotective effect of the ethanolic extract of Gynura procumbens was most effective when administered at the dose of $300 \mathrm{mg} / \mathrm{kg}$. This was also conveyed by Lau et al. (2018) in their research, explaining that the administration of Gynura procumbens extract at $300 \mathrm{mg} / \mathrm{kg}$ was able to prevent a significant increase in malondialdehyde levels, an indicator of lipid peroxidation.

When reaching its toxic dose, paracetamol metabolism through the sulfation and glucuronidation pathways will be saturated, and consequently more drug fractions will be oxidized into NAPQI. This will subsequently reduce GSH reserves, leading to the binding of NAPQI to sulfhydryl and glutathione in cellular proteins that eventually disrupts the homeostasis. Furthermore, it can cause an activation of caspases (in this case caspase-9 and caspase-3) and lysosomal enzymes that would initiate cellular apoptosis (Waring et al., 2010; Ghodke et al., 2015; Mazer and Perrone, 2008).

Besides forming bonds with cellular proteins and glutathione, NAPQI also stimulates the formation of ROS molecules, which will react with cellular proteins and triggers the lipid peroxidation process. Lipid peroxidation is one of the important mechanisms in the process of cellular and organ damage due to paracetamol (Aycan et al., 2015; Canayakin et al., 2016). This may support the contention that Gynura procumbens has an antioxidant mechanism that may be beneficial to protect the renal toxicity induced by paracetamol toxic dose.

\section{CONCLUSION}

It can be concluded that the ethanolic extract of Gynura procumbens leaves can protect the kidney function and histological structure at the dose of $300 \mathrm{mg} / \mathrm{kg}$. This is indicated by a decrease in creatinine and urea levels as well as the improvement in the histological structure of the kidney tissue.

\section{REFERENCES}

Aycan, I.O, Tokgoz O., Tufek A., Alabalik U., Evliyaoglu O., Turgut H., et al., 2015. The Use of Thymoquinone in Nephrotoxicity Related to Acetaminophen. Int J Surg. 13: 33-7.

Canayakin, D., Bayir Y., Kilic Baygutalp N., Sezen Karaoglan E., Atmaca H.T., Kocak Ozgeris F.B., et al., 2016. Paracetamol-Induced Nephrotoxicity and Oxidative Stress in Rats: The Protective Role of Nigella sativa. Pharm Biol. 209(March): 1-10. 
Djabir YY, Arsyad A, Murdifin M, Tayeb R, Amir NM, Kamaruddin FA, et al. Kleinhovia hospita extract alleviates experimental hepatic and renal toxicities induced by a combination of antituberculosis drugs. J Herbmed Pharmacol. 2021;10(1):102-108.

Djabir YY, Adnan J, Amaliah N, Ramli N, Sartini S, Mamada SS, Usmar U. Roselle (Hibiscus sabdariffa L.) calyx water extract ameliorates isoniazid and rifampicin induced liver and renal injuries in rats. J Herbmed Pharmacol. 2021;10(3):296-303.

Fadli, M.Y., 2015. Benefits of Sambung Nyawa (Gynura procumbens) Subtance as Anticancer. Jurnal Majority, 4(5).

Ghodke, Y., Anderson P.L, Sangkuhl K., Lamba J., Altman R.B., Klein T.E., 2015. Pharm GKB summary: Pathways of Acetaminophen Metabolism at The Therapeutic Versus Toxic Doses. Pharmacogenet Genomics.25(8): 416-26

Ikawati, Z, 2010. Cerdas mengenali obat. Kanisius.

Ismail, M.A.H., Bahari, E.A., Ibrahim, F.S., Dasiman, R. and Amom, Z., 2016. Effects of Gynura procumbens extract on liver function test of hypercholesterolemia induced rabbits. Jurnal Teknologi, 78(6-7).

Kemenkes RI. 2017. Situasi Penyakit Ginjal Kronis. Depkes RI.

Lau, S.H.A., Sartini, S. and Lallo, S., 2018. Potensi Antioksidan Ekstrak Etanol Daun Sambung Nyawa (Gynura procumbens) Terenkapsulasi Maltodextrin dan Pengaruhnya Terhadap Kadar MDA Darah Tikus Wistar (Rattus novergicus) Jantan yang Diinduksi CCL4. Majalah Farmasi dan Farmakologi, 22(3), pp.93-98.

Lorz, C., Justo, P., Sanz, A., Subirá, D., Egido, J. and Ortiz, A., 2004. Paracetamol-induced renal tubular injury: a role for ER stress. Journal of the American Society of Nephrology, 15(2), 380-389.

Malole M.B.M dan Pramono C.S.U. 1989. Pengantar Hewan-hewan Percobaan di Laboratorium. Bogor: Pusat Antara Universitas Bioteknologi IPB.

Mazer, M. and Perrone, J., 2008. Acetaminophen-Induced Nephrotoxicity: Pathophysiology, Clinical Manifestations, And Management. J Med Toxicol,4(1): 2-6

Mitchel dalam Gulfron M. 2001. Gambaran Struktur Histologi Hepar Dan Renal Mencit Setelah Pemberian Perlakuan Akar Rimpang Jahe (Zingiber officinale) Dengan Dosis Bertingkat. Jurnal Kedokteran Yarsi.

Pranandari, R. and Supadmi, W., 2015. Faktor risiko gagal ginjal kronik di unit hemodialisis RSUD Wates Kulon Progo. Majalah farmaseutik, 11(2), pp.316-320.

Purwitasari, R., 2016. Efek Nefroprotektif Ekstrak Daun Karamunting (Rhodomyrtus Tomentosa [Aiton] Hassk.) Terhadap Nefrotoksisitas Yang Diinduksi Asetaminofen. Jurnal Mahasiswa PSPD FK Universitas Tanjungpura, 3(1).

Wahyuni, Enggar, Kumorowati, Pitriani, Suardi, Sukri, dan Yunus M, 2012. Buku Panduan Kerja Laboratorium Patologi. Balai Besar Veteriner Maros. Edisi 2 Hal 1-21

Waring W.S., Jamie H. and Leggett G.E. 2010. Delayed Onset of Acute Renal Failure After Significant Paracetamol Overdose: A case series. Hum Exp. Toxicol. 29 (1): 63-8. 